\title{
Origins and Development of ACRL
}

Editor's note: In 1956 this statement written by William H. Carlson appeared in the ACRL Organizational Manual. There are many striking similarities between the frustrations and inactions experienced by our predecessors and the present dissatisfactions so vocally expressed by many ACRL members. Because the issues bear heavily on the question of federation for $A C R L$, the editors decided to reprint part of the original statement.

The Association of College and Reference Libraries was a long time aborning. It has its roots, dimly but discernibly, in the first convention of American librarians in New York City in 1853, for university librarians were prominent among the men assembled in that historic meeting. In the second general meeting of librarians on the North American continent, the great organizational convention of the American Library Association in Philadelphia in 1876, its beginnings are more clearly seen, for there too university and college librarians played a major role, as they have throughout the entire evolution of librarianship toward the status of a true profession. This being so, it is an interesting and in some ways a strange phenomenon that it should have taken almost a century, from the earliest beginnings, for college, university, and reference librarians to combine themselves into a full-fledged and effective association.

The reasons for the long, slow, and sometimes painful evolution of ACRL lie in the fundamental similarity of the basic problems of all libraries, partly in the wide range of interests of college librarians, but most of all in the organic structure of the parent American Library Association as originally established, with college librarians taking a leading part. The great organization brought to life in Philadelphia in 1876 was created in the spirit of similarity of all libraries. It was not designed to recognize special phases of library work, nor to facilitate autonomy of organization and effort for such specialized work within its structure. It took it more than sixty years, to its considerable detriment, to fully recognize that librarianship, while possessed of a fundamental unity, was becoming increasingly specialized and that those following varied library specialties could best grow, develop, and carry their libraries forward by working and planning autonomously together. The formative period of ACRL is consequently a history of a slow, halting, sometimes disgruntled but only in its later stages an aggressive search for autonomy with- in the hampering framework of its parent association.

\section{Finst Separate \\ College and Reference Meetings}

In the earliest ALA years, when librarians were concerned, in a formative sense, with the basic fundamentals of acquisition and organization of materials and with standardized equipment, specialized types of library work did not require separate consideration. It did not take long, however, as libraries grew and developed and as the American Library Association oriented itself more and more toward public libraries, for the need of emphasis on other kinds of library work to assert itself. By 1889 the state librarians at the St. Louis convention felt this need sharply enough to set themselves up as a separate organization affiliated with the ALA. At this same conference, the college librarians were similarly feeling the need of meeting and working separately to consider and discuss problems peculiar to college libraries. This took the shape of an informal meeting of thirteen college and university librarians who discussed matters pertaining to the operation of college libraries and who, before adjourning, voted on the motion of W. I. Fletcher, of Amherst, that a College Library Section be organized at the next conference of the ALA. Since these first steps toward specialization, five separate library associations affiliated with the ALA have been organized, while twelve entirely separate associations have come into being. Undoubtedly it was in part due to the inflexible structure of the ALA that so much associational development took place outside its organization rather than inside.

While ACRL stems directly from this 1889 meeting of thirteen librarians in St. Louis, it took another fifty years for it to complete its gestation and achieve autonomy as an integral part of the parent ALA. True to the resolution of the thirteen at St. Louis, a separate meeting of college librarians was held at the ALA White Mountains conference of 1890 with W. I. Fletcher as chairman and G. T. Little of Bowdoin as secretary. It is of special interest that papers presented at this first formal meeting dealt with faculty status for college librarians and seminar libraries, both still vital subjects these sixty years later. This separate White Mountains meeting was noted as an important development by editors C. A. Cutter and P. L. Ford of the Library Journal. College Libraries, they said, "have needs and interests differing in many respects as radically from the Free Public Libraries as have the state libraries." 


\section{ARE THE PEOPLE WHO USE YOUR PERIODICALS COLLECTION MAKING IT DIFFICULT TO KEEPA PERIODICALS COLLECTION?}

Since periodicals are almost always printed on paper, and paper is almost always vulnerable, we've developed probably the only sure method of safeguarding them.

We've dispensed with the paper.

By ordering your periodicals on microfilm from us, you get everything on the printed page but the page. This not only discourages people from taking part of your periodicals home; it makes it virtually impossible for them to do it.

A page the size of the one on the left reduces to less than a square inch on microfilm. Anyone ingenious enough to tear out an article from a page that size would probably be smart enough not to try.

This isn't to say that an entire roll of microfilm couldn't turn up "missing." (It's unlikely, since the film is useless without a reader.) But if it ever should, you could replace it for far less than it would cost to replace the original periodicals - which are sometimes irreplaceable at any price.

So if you're starting a periodicals collection, or expanding the one you have, you might consider microfilm.

Not just because of the space you save.

Because of the periodicals you save.

For more information, write: University Microfilms, Dept.I5, 300 North Zeeb Road, Ann Arbor, Mich. 48103. 
In spite of this recognition of differing needs and interests the college librarians were apparently reasonably content to meet and discuss affairs and developments of mutual interest without any clearly defined separateness. At the Philadelphia Conference of 1897 there was some further development. There W. I. Fletcher, for many years one of the moving spirits of the college group, served again as chairman of the section on College and Reference Library Work. Before a meeting of the section he said that after twenty-one years the ALA could put away childish things and enter a new era. This was manifest, he hopefully maintained, in the suggestions that the ALA be re-incorporated to become a truly representative body. He noted with satisfaction that the Association was, for the first time, meeting at that conference by clearly scheduled sections. Subsequent developments, unfortunately, did not bear out Fletcher's optimistic analysis.

At this 1897 conference a committee on organization of the college section, consisting of Willard Austin, Olive B. Jones and Clement W. Andrews, brought in a report recommending that branch organization be such that any ALA member who felt that his work fell in the college area should have full privileges to participate in the discussions of the section. It also recommended that the name "College and Reference Library Work" be retained. A constitution and bylaws were, however, not suggested. Under the very loose and informal organization proposed by this committee, the college librarians continued to meet within ALA for another twenty-five years. The word "work" however, was apparently tacitly dropped from the name which quickly became "College and Reference Libraries Section."

\section{Reorgantzation and First Constitution}

It was not until the Hot Springs Conference of 1923 that the section, under the chairmanship of W. E. Henry of the State University of Washington, got around to reorganizing and, for the first time, to adopting a constitution designed to provide a more satisfactory relation with ALA. This move was probably in response to increased grumblings of discontent among the college librarians about the lack of emphasis at headquarters in annual conferences and in publications on the problems and needs of college libraries. These were complaints which were to become increasingly audible and insistent in the next fifteen years.

The constitution, as adopted in 1923, provided for a chairman, a secretary, and three directors, with the treasurer of ALA also serving as the treasurer of the section. Dues of $50 \mathrm{c}$ per member, outside the ALA dues scale, were established. This move toward formal status apparently had a stimulating effect, as attendance at the Saratoga Springs Conference of
1924 rose to 240 as compared with 90 in the previous organizational year. At Saratoga Springs the bylaws originally adopted were changed, eliminating the designation of the ALA treasurer as secretary and assigning the treasury function to the secretary. A requirement for auditing of the limited funds of the section was also dropped.

\section{Growing Discontent}

Under these revised bylaws the College and Reference Libraries Section continued to meet for a period of years with only limited attendance and interest and mounting evidence of discontent among college librarians over their status within the ALA. This developed to the point where there was increasing talk of organization of college and university librarians into an entirely independent and separate association. Symptomatic of this trend was the Administrators Round Table of the section at the 1931 Conference. There Nathan Van Patten discussed the question, "Is a Separate Organization of College and University Libraries Needed?" He emphasized, within the college and university group, the differing needs and interests of the larger universities and the small colleges. It is from this meeting, and very probably this paper, that the Association of Research Libraries sprung.

. . . It was emphasized, at this meeting, that many important projects, such as the Union List of Serials, had been carried out entirely independently of ALA headquarters. It was also suggested that the section be made a subsection of the American Association of University Professors.

As a result of criticisms and suggestions such as these the ALA Council, at this same 1931 conference, authorized the appointment of a College Library Advisory Board which was to take an important part in college library affairs in a number of directions. One of the first assignments of this Board, which was established under the chairmanship of Donald Gilchrist of Rochester, was to prepare for council a statement on college library services which might be handled at ALA headquarters. Significantly, and as an evidence of the weakness of the College and Reference Libraries Section, this important committee was appointed, not by the section, but by the ALA Executive Board. Further council action recognizing the needs of the college libraries was its approval, at the New Orleans Conference of 1932, of the recommendation of the new College Library Advisory Board for a full-time secretary and staff at headquarters. . . .

These recommendations of the College $\mathrm{Li}$ brary Advisory Board, clear and specific as they were, and fully approved by the council, nevertheless languished unfulfilled in the morass of ALA and headquarters procedures, pri- 
orities, and financial commitments. Under this situation college and university librarians were becoming more and more restive and there was increasing talk, in convention corridors, in meetings, and in correspondence of an entirely independent college and universities library association.

\section{Reorganization Committee Appointed}

It was at the Richmond convention in 1936 that the College and Reference Section took the first direct step toward an autonomous association within ALA. Dissatisfied with its weak and powerless condition and acutely aware of mounting criticisms it appointed a strong reorganization committee under the able and dynamic leadership of Charles Harvey Brown of Iowa State College, who was also, strategically, to serve as chairman of the Third ALA Activities Committee. This Brown Committee at once undertook to review the entire history of the College and Reference Section and to bring in a comprehensive and far-reaching report which is the key document of ACRL history.

The committee reviewed the many years of the College and Reference Section as a weak and struggling unit of the ALA and its consequent inability to attract and sustain interest in college library work and activities. It noted that the section's only source of funds was a small separate dues fee, superimposed on ALA dues; that the College Library Advisory Board was an agency of the ALA Executive Board and not of the Section; that in the last fifteen years only one college librarian had been elected to the Executive Board; that no progress had been made toward the appointment of a headquarters secretary for college affairs, as approved by the council in 1932, and that most of the work at headquarters did not concern itself with college interests and affairs. It reported on the basis of a questionnaire sent to 1,170 college and university librarians, and to which it received 321 replies, that a much stronger college and reference section was essential. It found, although by a rather slender majority, that the questionnaire respondents believed that it was preferable to constitute a revitalized organization within the ALA.

The Brown Committee further found that the continuing failure of college and university librarians to achieve satisfactory organization was not due to a lack of interest on the part of ALA officers but to the intrinsic nature of the ALA itself, which was not constituted to encourage the work of special groups and to permit them self direction plus a share of dues paid. It suggested that the entire ALA be reorganized to permit the establishment of autonomous units concerned with specialized phases of library work. This important document probably saved the ALA from exploding into an extensive fragmentation of associational interests, efforts and work. With discernment and statesmanship it placed a finger squarely on the factors which had prevented satisfactory organization of college and reference librarians and of other non-public librarians for more than a half century.

\section{The Association Is Created}

The principal item of business at the Kansas City Conference of 1938 was consideration of the reorganization committee report which by that time had reached a third draft stage. The report was adopted and bylaws were approved reconstituting the College and Reference Section as the Association of College and Reference Libraries, a division of the ALA, with five subsections: College Libraries, Junior College Libraries, Reference Librarians, Libraries of Teacher Training Institutions, and University Libraries. At long last the college, university and reference libraries, after many years of semi-frustration and groping, were under way with an effective organization that was an integral part of ALA.

. . . To the section family there was added, almost immediately, the agricultural libraries, by petition, and, in 1941, the Engineering Libraries Section. These two sections were com-

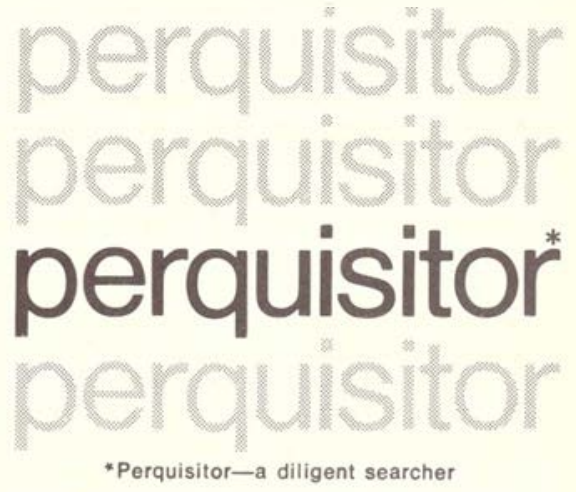

When you have a backlog of literature searches to do and time is running out, use ISI Search Service. With Search Service, your backlog is eliminated quickly, efficiently, and most economically. What's more, when ISI does your searching, you take advantage of one of the world's largest scientific data bases. The same one that's used to prepare the Science Citation Index ${ }^{\circledR}$ and $A S C A{ }^{\circledR}$.

Our information-savvy perquisitors are eager to help with your searching. Call today or write dept. 12-296a for details on ISI Search Service. s197ו 15.

Institute for Scientific Information 325 Chestnut Street, Philadelphia, Pennsylvania 19106 Tel.: (215) 923-3300, Cable: SCINFO. TELEX: 84-5305 
bined in $195 \mathrm{I}$ as the Pure and Applied Sciences Section to bring ACRL to its section status as of 1956.

\section{Things Begin to Happen}

The effect of autonomous status for the college librarians within ALA was immediate and electric. Interest in the new association zoomed, convention programs multiplied and took on additional zest and stature. Membership increased rapidly over the few hundreds of the College and Reference Section. The College Library Advisory Board, which had done yeoman's service during the thirties, felt that it could now safely recommend itself out of existence. Most important of all, College \& Research Libraries was born.

It would be difficult to over-assess the vitalizing and stimulating effect of College \& Research Libraries on college librarianship and on the growth and development of ACRL. "The time has long passed," said Editor Kuhlman, in his introductory statement, "when a single general library organization and its official journal were adequate to meet the professional needs of college, university, and reference librarians." Noting Abraham Flexner's emphasis, in his analysis of a profession, on a medium of communication, Mr. Kuhlman said, "It has been the absence of a professional journal devoted specifically to the interests of college, university and reference libraries which no doubt accounts, to a large extent, for the lack of a definitive literature dealing with these institutions." ...

While College \& Research Libraries was off and running immediately, not so the organization for which it was the official organ.
The ALA could not easily change its spots. It took time, in spite of its reorganized machinery and structure, for it and its headquarters staff to reorient thinking, activities and financing to the new order of things. Funds for the longawaited and long-promised executive secretary at headquarters were still not available. Rumblings of discontent among college librarians grew correspondingly. There was much talk and some planning to take ACRL out of ALA entirely and establish its headquarters on some college campus. Officers of the early 1940 's were under considerable pressure to take this drastic step.

\section{A Headquarters Staff at Last}

It was not until ALA came to the hard decision to draw on principal to finance a headquarters staff for ACRL that the council approval of 1932 was finally consummated. This happened in April of 1947. . . .

.. ACRL has grown rapidly in prestige and accomplishments. It has achieved a somewhat uneasy but reasonably effective division of membership dues with its parent ALA so that it must no longer, in effect, eat seed corn. It has also become soundly integrated with its sections and better integrated with the ALA. Its membership is now over 5,400 , it is in a healthy financial condition, its official journal ranks with the best of its class in whatever field, it is issuing other publications of stature, its sections are thriving, and it is amply calling forth intelligent and able leadership from its ranks. It took a long time, but one hundred years after the beginnings, college, university, and reference librarians have a strong, virile, and effective organization equal to the difficulties, opportunities and challenges ahead.

\section{From the ACRL President}

Since Midwinter:

1. ALA Reorganization. The ACRL Executive Committee has had an opportunity to see a preliminary copy of the latest ACONDA findings which are to be presented to membership at Dallas. In it there is a proposal for a further study of reorganization, but suggesting either the triad or the federation concept. ACRL still supports the federation proposal. It also supports the new ACONDA proposal for further study and suggests that ACRL recommend that no interim changes be made in the structure or organization of individual aspects of ALA until a final decision on the reorganization proposal is made.

In my earlier memo to you in the News, I indicated that we would keep ACRL member- ship informed of our own study on the matter of federation. Following the Midwinter Meetings in Los Angeles, we set up three task forces to analyze and prepare recommendations, assuming federation, with respect to three areas of concern to us. These are listed below with the names of ACRL members serving on them who, I am sure, would be happy to receive any suggestions from the membership.

Structure: Joanne Harrar, University of Georgia; William Pullen, Georgia State College; Hal Stone, Los Angeles City College.

Goals: Louis Jacob, University of Pennsylvania; Marc Gittelsohn, University of California, Berkeley; Darrell Lemke, Consortium of Universities, Washington.

Finances: Mark Gormley, Wayne State 